\title{
Taiwan in the 20th Century: Model or Victim? Development Problems in a Small Asian Economy
}

\author{
Christopher Howe
}

Economic performance in the long term is the result of interaction between an economy's internal characteristics and its external environment. The internal characteristics include economic and social institutions, governmental and legal frameworks, natural and human resources, and locational factors. The external environment consists of two parts, one made up of foreign resource configurations and potential opportunities for fruitful economic relationships, and the other of power networks and "rules of the game." These broader frameworks determine the extent to which potential economic gains can actually be realized.

The relative importance of internal and external factors is likely to depend on the size of any particular economy. "Size" is here defined to include space, resources, organizational capabilities and human resources. In general, larger economies depend less on external environments. This is partly because they have more potential for economies of scale and an internal division of labour and partly because they tend to greater self sufficiency in natural resources. These effects are reinforced by the fact that larger is often politically more powerful, and hence more able to set political parameters and the rules of the game for others - even if these relative strengths are more regional than global.

Smaller economies, on the other hand, have less freedom. They are constrained in significant ways by absolute domestic production and resource limits and need access to international markets for economies of scale and specialization and access to international stocks of knowledge and know-how of all kinds. Their problem is that the modes and channels of access to outside markets and resources are basically shaped by others. In extreme cases a small economy may be virtually incorporated in a larger political entity or, at the very least, will have to play entirely by the rules of the game set by the more powerful.

Today, Taiwan remains a small economy. It is less than 14,000 square miles in extent (half the size of Ireland), and has a population of only 22 million. Yet it has achieved an impressive per capita income with good health and wealth indicators. It is in the top 16 trading nations, has been rated fourth in World Competitiveness rankings and has strong technology and improving corporate capabilities. Thus the question is: what have been the roles of internal and external factors in this story? And further, what does the pattern reveal about Taiwan's present and prospective situation? The analysis begins with Taiwan's "initial conditions," prior to the beginning of the "century" that these collective articles focus on. 


\section{The World Before 1895}

The essential feature of the Asian world prior to the Opium War was the fact that China and Japan both operated distinctive systems of seclusion or the "closed door." These systems were a reflection of their mutual antagonism and also devices to insulate their domestic polities more generally from the shocks of external intrusion. The long reigns of the Ming and Qing in China and of the Tokugawa in Japan, are evidence of the success of these endeavours. ${ }^{1}$

In spite of these barriers, trade and some resource movements did occur. At one level this was achieved by the Chinese Tributary System which operated through a small number of controlled, legitimate entry points such as Guangzhou. In Japan there was a system of authorized ("Seal") cargo movement, and provision was made at Nagasaki for a large enclave of Chinese merchants and a much smaller trading base for the Dutch. ${ }^{2}$ These politically restricted channels were insufficient for the volume of profitable intra-Asian (especially Sino-Japanese) exchange available and consequently "excess" trade took the forms of piracy and illicit flows of various kinds. These frequently went through intermediaries to create triangular trading patterns. One central point was the Ryūkyū Islands. Another was Taiwan.

When the Europeans arrived in Asia in the 16th century they inserted themselves into these politically determined patterns of economic activity. In the process they actually served to swell the volume of intra-Asian trade as well as conducting the long-distance trade between Asia and Europe in high value goods which was their original purpose. Thus as early as the late 16th century Taiwan was enjoying its first phase as an Asian trading hub, with particularly close linkages to mainland China and southern Japan.

In the 17th century, the Japanese, Spanish and Dutch all intervened in Taiwan's affairs. The Dutch proved most effective and actually occupied part of it (with Chinese permission) between 1624 and 1655. While this was primarily a strategy to gain access to China, the Dutch also encouraged migration from Fujian and Guangdong in order to develop an export economy based mainly on sugar. Through the Dutch connection, Taiwan became a regional emporium and part of a world-wide trading network that embraced the Middle East, Europe, Africa and Brazil. ${ }^{3}$ It was so much so, for example, that when the sugar harvest failed in Brazil, the Dutch supplied Europe and the Middle East from China, through Taiwan.

1. Ronald Toby, State and Diplomacy in Early Modern Japan (Stanford: Stanford University Press, 1991).

2. Marius B. Jansen, China in the Tokugawa World (Harvard: Harvard University Press, 1992). We owe our understanding of the tribute system to the researches of Takeshi Hamashita. See for example his "The tribute trade system and modern Asia," in A.J.H. Latham and Heita Kawakatsu (eds.), Japanese Industrialization and the Asian Economy (London: Routledge, 1994).

3. Wm Campbell, Formosa under the Dutch Described from Contemporary Sources (London: Kegan Paul, 1903), esp. ch. 3. Jonathan I. Israel, Dutch Primacy in World Trade, 1585-1740 (Oxford: Clarendon Press, 1989). 
The Ming dynasty never recognized Taiwan as "Chinese," but under the Qing it was incorporated and became a prefecture of Fujian. By the 18th century, under restored Chinese rule, Taiwan became a flourishing if small economy. Its main city, Taiwanfu (renamed Tainan after 1887), was described in one Western source as "large, very populous, and extremely commercial." Shops in the long, wide streets of Taiwanfu were loaded not only with local rice, sugar, tobacco, salt and meat, but also with cotton, silks, rare medicinal herbs, and all manner of goods from China, Europe and the Indies. In the same period, some urbanization was taking place in the north, including the expansion of Hsinchu, then the seat of a well known academy of scholars. ${ }^{4}$

In the mid 19th century, Taiwan became connected to the Asian trading system in a completely new way. Between 1858 and 1860 it was opened to foreigners through the Treaty Port system of which four Taiwanese cities eventually became members. These were Taiwanfu and Takow (Kaohsiung) in the south and Tamsui and Keelung in the north. This development followed and was accompanied by various other activities including a series of British naval surveying expeditions and a visit by the botanist Robert Fortune, sent by the British East India Company to examine tea and other varieties of cultivation. ${ }^{5}$ Status as a Treaty Port linked Taiwan to other cities in the system, where similar expatriate business activities existed and between which people, intelligence and commercial contacts circulated easily.

The combination of Western impact and a relatively active, reforming Chinese administration produced significant overall development. Output, trade and tax revenues from trade all grew swiftly from 1860 to the 1890 s and, in contrast to the mainland, this took place with little detriment to the traditional economy. Also, with tea based in the north, the economic balance of power had by the 1880s shifted decisively away from its traditional southern base. ${ }^{6}$ This growth was supported by immigration, which occurred as population in the distressed coastal provinces moved to take advantage of the developing frontier economy of Taiwan. At the same time, a comprehensive system of walled cities was completed and these supported Confucian Temples and Academies, reflecting the power of mainland authority and the significance of official ideology.

Thus by the 1890s, the Taiwanese economy had a complex history of international linkages, a subsistence sector, and a strong, modernizing

4. Abbe Grosier, in Joseph-Anne-Marie de Moyriac de Mailla, Histoire Generale de la Chine (Paris, 1785), Book XIII; Harry J. Lamley, "The formation of cities: initiative and motivation in building three walled cities in Taiwan," in G. William Skinner (ed.), The City in Late Imperial China (Stanford: Stanford University Press, 1977).

5. William Blakeney RN, On the Coasts of Cathay and Cipango, Forty Years Ago (London: Elliot Stock, 1902), ch. 4; Robert Fortune, A Residence among the Chinese (London: John Murray, 1857), ch. 11.

6. This phase is well described in Lin man-Hung, Cha, tang, zhangnao ye yu Taiwan zhi shehui bianqian, 1860-1895 (The Tea, Sugar and Camphor Industries and Social and Economic Change in Taiwan, 1860-1895) (Taipei: Lianjing Press, 1997). According to data quoted by Lin, between $1868 / 69$ and $1893 / 94$, total exports grew at $8.3 \%$ per annum and exports of tea through Tamsui at $17.8 \%$ per annum. 
export sector based on rice, tea, sugar, camphor and other goods. ${ }^{7}$ In Treaty Port terms, it has been estimated that per capita trade from Tamsui and Takow (the value of exports from these ports per head of the Taiwan population) was higher than that for any comparable figure relating trade in ten major Chinese Treaty Ports to their respective provincial populations. ${ }^{8}$ And although westerners were indeed very important in opening the export trade, local merchants were actively beginning to insert themselves into the trading chain. The economy that the Japanese took over in 1895 was, in other words, far from the primitive, subsistence structure terrorized by head hunters, as sometimes portrayed. On the other hand, it clearly lacked a physical and institutional infrastructure for comprehensive modernization and growth and was driven, not by indigenous strengths, but by a combination of Western and cross-Straits influences. These influences reflected a strange combination of the final chapter of the relationship between Taiwan and the imperial court, and a rampant phase of Western overseas expansion. The mainland impact, however, even when allied to Western forces bridging the Straits, only gave rise to levels of trade far below their potential. This reflected two problems. Institutionally, the failing Qing administration remained wedded to the concept of a controlled national commercial system, with maritime trade regulated by restrictions similar to those governing internal, waterborne trade - that is, the Taiwan Straits were treated as a branch of the Grand Canal. The other problem was that the coasts of Taiwan, although so close to the mainland, were in fact inhospitable to large-scale maritime development, restricted as this was by contemporary technologies governing shipbuilding, harbour and lighthouse construction. The journey across the Straits took only one to three days but the western shores of Taiwan encompassed strong and confusing currents, unpredictable winds, reefs and sandbanks that appeared with no warning, and a crashing surf line only navigable by native rafts. For many vessels, safety required being out of sight of the coast, and even for the experienced, The China Pilot recommended only Keelung in the far north as a safe shelter from typhoon force storms. ${ }^{9}$

\section{The Japanese Colonial Period, 1895-1945}

The weakness of China in the late 19th century made the relatively independent but economically promising island of Taiwan an inviting prospect for colonial occupation. Old China hands urged the British to

7. A great deal of information on the state of Taiwan at the turn of the century is in James W. Davidson, The Island of Formosa, Past and Present, first published 1903, republished by SMC Publishing, Taipei, 1992. On rice cultivation, see also the description in G.L.Mackay, From Far Formosa (Edinburgh: Oliphant, Anderson and Ferrier, 1896).

8. Lin man-Hung, The Tea, Sugar and Camphor Industries, p. 6.

9. These difficulties are well described by Pickering and others and especially by John W. King RN, The China Pilot, The Coasts of China, Korea, Tartary ... Formosa etc. (third ed.) (London: The Admiralty, 1861), ch. 8. This guide also notes the difficulties presented by high tidal fluctuation and sandbanks on the Min river on which Foochow was situated on the opposite side of the Straits. 
intervene, but London was satisfied with the combination of Hong Kong and the ever expanding Treaty Port arrangements on the mainland of China. ${ }^{10}$ The French occupied Keelung during the war of 1884-85, and there was some interest too from the Germans. For all Western nations, the presence of coal made Taiwan a serious prospect for military and civilian shipping reasons. ${ }^{11}$ However, it was Japan that finally secured Taiwan and made it the foundation of its formal colonial empire.

Japan had viewed with concern Western naval presence in a region so close to its own islands and inside a sphere of commercial interest dating back to the 16th century. The primary motive for acquiring Taiwan, therefore, was strategic and legal rather than narrowly economic. In this sense, Taiwan was not exceptional. Most of Japan's formal and informal empire was physically adjacent and strategically critical - much of it (such as Korea and Manchuria) developed to resist an expansionary Russia. $^{12}$

Under the 1895 Treaty of Shimonoseki, Japan secured Korea as a sphere of influence and obtained in China an unprecedented and growing range of economic rights and concessions, including the right to construct railways and make direct investments in factories, something that the Western powers had never done. ${ }^{13}$ This treaty and the acquisition of Taiwan placed Japan among "The Powers." Whereas in 1858-60 Japan had been forced to submit to unequal treaties and imposition of the Treaty Port system, by the revision of the Ansei Treaties and consequent resumption of tariff autonomy (1899-1909), the rehabilitation of its international status was complete, albeit in a different world system from that of traditional Asia.

By the early 1900s, moreover, Japan could see clear potential economic benefits in Taiwan. Business circles and government were by then concerned with three issues: emerging difficulties with the rice supply, the long-standing national sugar deficit and the entirely new problem of "surplus population." 14 Potentially, Taiwan had some solutions to all

10. See the preface to W.A. Pickering, Pioneering in Formosa. Recollections of Adventures among Mandarins, Wreckers and Head-Hunting Savages (London: Hurst and Blackett, 1898). Both France and Britain were offered Taiwan as a protectorate, with China retaining sovereignty. See Hosea Ballou Morse, The International Relations of the Chinese Empire. Vol. 111. The Period of Subjection, 1894-1911 (London: Longmans, Green, 1913), p. 48.

11. The French attack on Taiwan and the occupation of Keelung (1884) were major events, involving the latest naval technology, the torpedo. Marc Benoist, Courbet. Marin Legendaire (Admiral Courbet. The Legendary Naval Officer) (Paris: Loisirs), ch. 6, "Formose."

12. See articles by Marius B. Jansen and Mark R. Peattie in Ramon H. Myers and Mark R. Peattie (eds.), The Japanese Colonial Empire, 1895-1945 (Princeton: Princeton University Press, 1984). Also, Yamamoto Yuzo, "Shokuminchi keiei" ("The management of colonial territories"), in Nakamura Takafusa (ed.), Nihon keizaishi, (6) Nijū kōzōo (The Economic History of Japan, 6, the Dual Economy) (Tokyo: Iwanami Shoten, 1989).

13. The gains were growing because after the initial treaty, a long list of supplementary instruments was drawn up, all involving further humiliation for the Chinese and further commercial gains for Japan.

14. On rice, Kawano Shigeto, Taiwan beikoku keizairon (The Rice Economy of Taiwan) (Tokyo: Yuhikaku, 1941), ch. 1. Sugar had been a perennial problem for Japan, which was not suitable for cane cultivation. Takekoshi Yosaburo reported that Japanese per capita sugar 
these difficulties. It had the basis of a rice economy, the climatic conditions and experience for sugar cane production, and the capacity to absorb Japanese at all skill levels. In the event, Taiwan did indeed contribute to the food and sugar supply, but did little for the "surplus population" problem. By the 1930s, moreover, Japan had identified a major new role for the Taiwan economy: that of being an East Asian economic hub in Japan's East Asian Empire and of serving as a base for military expansion to the south.

Japanese control and these broad colonial objectives constituted the main elements of the external environment of Taiwan's development during the first half of the 20th century. How far pursuit of these objectives served Taiwanese developmental and welfare interests is controversial. A number of pioneering Western scholars, including George W. Barclay and Ramon Myers, have taken a positive view. Myers has been particularly impressed by the significance of agricultural development in this period, and Barclay summed up with the assertion that Taiwan "... developed into one of the most successful colonial programs in the world." 15 Among Japanese scholars, Mizoguchi Toshiyuki has emphasized the point that real wages in Taiwan grew significantly and while he did not regard this as political justification for Japanese rule, he contrasts the Taiwanese experience with that of Korea, where colonial rule was brutal and living standards fell. ${ }^{16}$ Samuel P. S. Ho, the main economic historian of Taiwan in English, has also taken a favourable view of this period. ${ }^{17}$ Against these views there are numerous critics, both new and old. In the pre-war period, Yanaihara Tadao was highly critical of Japanese policies and institutions, and among Chinese scholars, Chou Hsien-wen, Tu Zhao-yan and more recently Ka Chih-ming have all written powerful and important critical works. ${ }^{18}$

\footnotetext{
footnote continued

consumption in 1888 was only 5 lbs per head, rising to 14 lbs in 1903 , which was still only one-fifth of British consumption at that time. Takekoshi Yosaburo, Japanese Rule in Formosa (London: Longmans, 1907), p. 242. On employment concerns, see press articles cited in Ōkura Zaibatsu Kenkyukai, Okura zaibatsu no kenkyū, Ōkura to tairiku (Okura Zaibatsu Research. Okura and the [Chinese] Mainland) (Tokyo: Kondo Shuppansha), p. 112.

15. George W. Barclay, Colonial Development and Population in Taiwan (Princeton: Princeton University Press, 1954), p. 7. Myers has written extensively on these topics; on agriculture see Carolle Carr and Ramon H. Myers, "The agricultural transformation of Taiwan: the case of Ponlai rice, 1922-42," in R. T. Shand (ed.), Technical Change in Asian Agriculture (Canberra: ANU Press, 1973). According to The Times (London), Japanese administration in Taiwan was also much admired by the British diplomat Sir Claude Macdonald, who exchanged views with the Taiwan government on his own colonial experiences in West Africa during a visit to the island in 1910. "The Japanese in Formosa," The Times, 23 March 1910.

16. Toshiyuki Mizoguchi, "Consumer prices and real wages in Taiwan and Korea under Japanese rule," Hitotsubashi Journal of Economics, Vol. 13, No. 1 (June 1972).

17. Samuel P. S. Ho, The Economic Development of Taiwan, 1860-1970 (Yale: Yale University Press, 1978), ch. 6. For a developed view of the mechanisms that produced this result, see also Ho's article in Myers and Peattie, The Japanese Colonial Empire, ch. 9.

18. Chou Hsien-wen, Riju shidai Taiwan jingjishi (An Economic History of Taiwan under Japanese Control) (Taipei: Bank of Taiwan, 1958) (two vols.). Tu Zhao-yan, Nihon teikokushugi ka no Taiwan (Taiwan under Japanese Imperialism) (Tokyo: Tokyo University Press, 1975). Chih-ming Ka, Japanese Colonialism in Taiwan. Land Tenure, Development, and Dependency, 1895-1945 (Taipei: SMC Publishing, 1995).
} 
From the viewpoint of this article, the important point to note is that Japanese colonial objectives were indeed designed not for Taiwanese structural change as such, but to serve Japanese domestic economic objectives, and these objectives were changed again to serve a wider regional division of labour, again led by Japan. In the first phase (1900-30) Taiwanese exports were to serve as a source of food and other materials, while in its imports Taiwan was to be a recipient of Japanese producer goods and capital. As a market protected from international competition, Taiwan was a valuable learning environment for industries and firms inexperienced in the export of heavy industry goods and in the making of successful foreign investments. ${ }^{19}$

The progress of the economy from 1905 to 1945 is summarized in Table 1. The key data in this table are those for population, GNE and export volume. The series are too aggregated and problematic to provide adequate guidance on issues of income distribution and the net effects of Japanese rule. They do, however, establish that substantial growth of output and exports took place. ${ }^{20}$

The early role of government in this development may be summarized as follows. First was establishment of basic administrative structures and colonial objectives. The latter emphasized the difference between Japanese and Western types of colonialism, with the Japanese seeking systems that ensured development and colonial financial self sufficiency and, in the long term, assimilation with Japan. Language, law and currency systems were important tools both of immediate political control and long-term assimilation. ${ }^{21}$ The second role of government was in decisions relating to public finances and monetary arrangements. The early fiscal problem was very serious because the costs of administration and public order and the need for physical infrastructure were so high and pressing. In the short term, recourse was had to public monopolies in camphor, opium and other commodities. For the longer term, cadastral surveys laid the foundations for agricultural taxation and a system that did indeed provide for colonial financial self sufficiency. The third governmental role was in the exploration of strategies to develop rice and sugar cultivation and related processing activities. ${ }^{22}$ And, finally, it played

19. Japan's structural problems in the 1920 s and their relation to colonial policies are discussed in Christopher Howe, The Origins of Japanese Trade Supremacy. Development and Technology in Asia from 1540 to the Pacific War (Chicago: Chicago University Press, corrected ed. 1999). Foreigners were pushed out of Japan very quickly. The British were eliminated from the tea and camphor trades and other non-Japanese foreign investment never got started. See Chou Hsien-wen, An Economic History of Taiwan under Japanese Control, vol. 1.

20. The distribution issue is tackled by Chih-ming Ka, Japanese Colonialism in Taiwan.

21. Japan established local Central Banks in its colonies, here the Bank of Taiwan. The Bank took Taiwan on to the Gold-Yen Standard and hence made it part of a currency bloc. The Bank of Taiwan later became famous for its bankruptcy, but in its early days it was a crucial factor in the growth of the Taiwan economy. Taiwan ginkōshi (History of the Bank of Taiwan) (Tokyo, 1964).

22. Chou Hsien-wen, An Economic History of Taiwan under Japanese Control has very detailed accounts of agricultural development. See also Kawano, The Rice Economy of Taiwan. This brilliant study was made under the guidance of Tobata Seiichi, arguably the most 
Table 1: Economic Indicators for Taiwan, 1905-1935

\begin{tabular}{|c|c|c|c|c|c|c|c|c|}
\hline & $\begin{array}{l}\text { Population } \\
\% \text { per } \\
\text { annum }\end{array}$ & $\begin{array}{c}\text { Gross } \\
\text { national } \\
\text { expenditure } \\
\% \text { per } \\
\text { annum }\end{array}$ & $\begin{array}{c}\text { Agricultural } \\
\text { production } \\
\% \text { per } \\
\text { annum }\end{array}$ & $\begin{array}{c}\text { Industrial } \\
\text { production } \\
\% \text { per } \\
\text { annum }\end{array}$ & $\begin{array}{c}\text { Export } \\
\text { volume } \\
\% \text { per } \\
\text { annum }\end{array}$ & $\begin{array}{c}\text { Real } \\
\text { wages in } \\
\text { manufacturing } \\
\% \text { per } \\
\text { annum }\end{array}$ & $\begin{array}{c}\text { Real } \\
\text { wages in } \\
\text { agriculture } \\
\% \text { per } \\
\text { annum }\end{array}$ & $\begin{array}{c}\text { Life } \\
\text { expectancy } \\
\text { at age } 1 \text { for } \\
\text { females } \\
\text { (years) }\end{array}$ \\
\hline $1905-20$ & $\begin{array}{c}1.25 \\
\text { (3.04 to } \\
3.66 \\
\text { millions) }\end{array}$ & 5.91 & 1.39 & 2.26 & 5.05 & 2.32 & 5.56 & $\begin{array}{c}34 \\
(1906)\end{array}$ \\
\hline 1920-35 & $\begin{array}{c}2.38 \\
(3.66 \text { to } \\
5.21 \\
\text { millions })\end{array}$ & 3.09 & 4.87 & 7.44 & 9.85 & 0.58 & -0.78 & $\begin{array}{c}51.5 \\
\text { (average } \\
1936-40 \text { ) }\end{array}$ \\
\hline
\end{tabular}

Note:

Not indicated in the population data are the scale of migration flows. Chinese flows were typically 20,00-30,000 per annum inward and outward. Japanese net inflows averaged 4,000 per annum. Minami Ryoshin, Taiwan no jinkō to keizai (Taiwan's Population and Economy) (Tokyo: IDE, 1971), p. 2. Sources:

Samuel P. S. Ho, The Economic Development of Taiwan, 1860-1970 (Yale: Yale University Press, 1978), p. 27; George W. Barclay, Colonial Development and Population in Taiwan (Princeton: Princeton University Press, 1954), p. 154. 
a role in the evolution of the private sector and the development of education. ${ }^{23}$

Direct involvement in the economy was supplemented by strong policies for public-private collaboration. In part these were a transfer of Japanese shokusan kōgyō policies of the late 19th century. These policies included an array of devices by which government investment led, but ultimately gave way to, private sector investment, including fiscal advantages, profit guarantees and other helps, including tariff and non-tariff protection. However, added to the old domestic formula were new ingredients supplied by the now maturing Japanese corporate sector. This was led by remarkable men including Okura Kihachirō, Masuda Takashi and Shibusawa Eiichi, who helped to develop these strategies in the context of Japanese activities in Manchuria, Taiwan and China proper, especially the Chang River Valley. In their view, the business problems arising from colonial expansion called for enhanced government investment, infrastructure provision, and an active diplomatic and security role to be played by the state to ensure the security of major investments and access to markets. Once government had laid the foundations, it would be the private sector with its capital resources, information systems and, above all, its highly trained personnel, that would be in a position to advance Japan's interests. Taiwan was a testing ground for both these ideas and for the companies involved. ${ }^{24}$

In agriculture, the distinctive feature of colonial policy was the use of Chinese cultivators in both rice and sugar sectors, and in some of the ancillary commercial and processing where small-scale business activity was possible. In sharp distinction to policy in Korea, in Taiwan the Japanese basically used indigenous cultivators but controlled their income and choices by developing Japanese monopsonistic power in the processing and commercial sectors. In the case of sugar there was thus from the outset a sharp distinction between the small-scale, labour intensive cultivation of cane, and the large-scale, mechanized processing and transportation end of the business. ${ }^{25}$ In rice, the shift to complete Japanese market control came somewhat later and was more complicated.

Two keys to this pattern were the nature of land-holding rights and the

\footnotetext{
footnote continued

distinguished Japanese economist of the 20th century. Like so many Japanese economists, Tobata started life as an agricultural economist reflecting the urgency of the rural crisis in pre-war Japan. He later had a decisive influence on post-war economic policy, which he was asked to expound in a formal presentation to Emperor Hirohito. The fact that Tobata regarded Taiwan's agriculture as an important area of study indicates the seriousness of the intellectual resources devoted to colonial questions.

23. Patricia Tsurumi, "Colonial education in Korea and Taiwan," in Myers and Peattie, The Japanese Colonial Empire. A detailed account of education activity in the 1930s can be found in, Taiwan Sotokufu, Taiwan jijōo (Taiwan Conditions) (Taipei: Taiwan Jihō Hakkōshō, 1933).

24. This viewpoint is discussed extensively in Okura Zaibatsu Kenkyukai, Okura Zaibatsu Research. Many Okura staff went from successful careers in Taiwan to work in Manchuria. 25. Ito Shigeru (ed.), Taiwan seitō kabushiki kaishashi (The History of the Taiwan Sugar Company) (Tokyo, 1939).
} 
introduction of the horai varieties of rice. As Ka Chih-ming has convincingly argued, traditional land ownership systems based on rights acquired through use and reclamation were, for urgent fiscal reasons, converted by the colonial government into absolute titles. This made subsequent forcible expropriation on a large scale impossible, although the public sector did gain much land as a result of the land survey exercise and other sharp practices. The horai varieties were needed to suit the tastes of Japanese consumers, and as their prices rose they became an exclusively export and hence cash crop. ${ }^{26}$ The net effect of this was that marketization of the rural and related sectors was rapid and far-reaching. Thus while the impact of Japanese policies on incomes and income distribution may well have been regressive and severe, and while the market was undoubtedly reinforced by coercion, a strong process of market acculturation did take place. $^{27}$

By the late 1930s, these strategies had produced not only the economic growth indicated in Table 1, but also the Japan-oriented trade structure shown in Table 2. Apart from Japan, other Asian destinations also appeared as Taiwanese trade partners. Indeed, for 1939, it is estimated that 97.81 per cent of all exports were directed to members of the East Asian Co-prosperity Sphere. Of the late Qing Taiwanese export staples, only tea remained as a commodity with a world market. But concentrated and distorted as this export structure was, the net result was that, apart from British Malaya, Taiwan exports per capita were higher than any other economy in Asia, Japan included. ${ }^{28}$

As the Pacific war approached, the role of Taiwan was to change once

Table 2: Japan's Share of Taiwan's Exports, Select Years, 1890-1939

\begin{tabular}{ccccc}
\hline & $\begin{array}{c}\text { Total exports } \\
\text { \% share }\end{array}$ & $\begin{array}{c}\text { Sugar exports } \\
\text { \% share }\end{array}$ & $\begin{array}{c}\text { Rice exports } \\
\text { \% share }\end{array}$ & $\begin{array}{c}\text { Tea exports } \\
\text { \% share }\end{array}$ \\
\hline $1890-99$ & 22.77 & 40.8 & 17.28 & 6.33 \\
$1920-24$ & 84.57 & 96.38 & 99.46 & 9.17 \\
$1935-39$ & 90.35 & 94.47 & 99.13 & 13.33 \\
\hline
\end{tabular}

Source:

Chih-ming Ka, Japanese Colonialism in Taiwan. Land Tenure, Development, and Dependency, 1895-1945 (Taipei: SMC Publishing, 1995), p. 66.

26. This is dealt with in works by Kawano, Tu and Chou.

27. See materials in Yanaihara Tadao, Tu Zhaoyan and Ka Chih-ming cited above. Dr Ka questions earlier Japanese Marxist views that marketization led to proletarianization. The role of coercion in agricultural development was carried over from Japanese experience. For example, when new rice borer resistant techniques were introduced into Saga prefecture, southern Japan, in the 1920 s, the local chief of police would tour the fields at night with a posse of ten officers, arresting farmers who were not complying, See Penelope Francks, Technology and Agricultural Development in Pre-War Japan (Yale: Yale University Press, 1983), p. 169. The role of the police in the Taiwanese economy is also emphasized by Lin Chung-hsiung, Taiwan jingji jingyan yibainian (Taiwan's Hundred Years of Economic Experience) (Taipei, 1998).

28. See Table 5, cited from the U.S. Department of Commerce data in Barclay, Colonial Development and Population in Taiwan, p. 33. 
again. The official yearbooks began to emphasize its role as a naval, air and war supply base for the Japanese advance to the south. ${ }^{29}$ This obviously had important implications for industrial development. However, the full significance of Taiwan's changing economic structure in the later 1930s is most clearly explained by Takahashi Kamekichi, whose master work on the subject appeared in $1937 . .^{30}$ Takahashi had a strong background in Japanese (and Manchurian) economic development and he brought to Taiwan a global framework of analysis. He saw the world moving towards an arrangement of "blocs" within which barter compensation would become common. Congruent with this, domestic resource allocation would be planned and subject to control (tôsei). In this new world, Japan would need to exchange agricultural goods from the Dutch East Indies and other Asian economies for its own industrial exports. This was the famous "flying" (hiyakuteki) mode of development. In addition, Takahashi analysed exhaustively Taiwan's agricultural sector, including the vexed problem of land prices. He concluded that with prospects for further cultivated area and productivity gains highly limited, and a world agriculture where a new agro-industrial revolution was producing huge, low-cost food surpluses, Taiwan must move on from its agricultural foundation to develop new forms of trading comparative advantage in Asia.

An examination of economic structure shows indeed that the share of science-based industries including chemicals, electrical generation, aluminium and man-made fibres was growing rapidly even as Takahashi was writing, and this trend continued. ${ }^{31}$ Trade data show that re-exports had risen from only 6 per cent of total exports in the 1900s to 26 per cent in 1934. Thus in Takahashi's view, Taiwan was already evolving towards being a service and high technology hub for the East Asian region. This direction had to be further advanced so that Taiwan could, in conjunction with Ōsaka and Kōbe, develop even further at the expense of Singapore, Shanghai and Hong Kong, from which the British were expected to be soon ejected. This orientation for Taiwan's Asian economy disappeared completely in the post war era, but it has a strong contemporary ring when viewed from the perspective of the 1990s.

\section{Conclusion}

Taiwan thus achieved significant growth and development under the Japanese. In half a century it proceeded through a major phase of agricultural development and was maturing in the direction of an industrial and service economy. Of all the colonial areas, only Taiwan

29. See introduction to Taiwan Keizai Nenpō Kankōsha, Taiwan keizai nenpō (Taiwan Economic Yearbook) (Taibei: Kokusai Nihon Kyōkai, 1942).

30. Takahashi Kamekichi, Gendai Taiwan keizairon (The Economy of Modern Taiwan) (Tokyo: Kokusai Nihon Kyōka 1937).

31. Shao You-zhi, Riju shiqi Taiwan shangye gonghui de fazham (1895-1937) (The Development of Trade Associations in Taiwan during the Japanese Occupation 1895-1937) (Taibei: Daoxiang Press, 1998). 
achieved a per capita income near to that of Japan itself. Agricultural exports remained the mainstay of trade until the late 1960s and the industrial and commercial legacy was also significant. For although dominated by large Japanese firms, in sharp contrast to Korea, the economy grew an active sector of smaller, Chinese firms. These were reinforced by the Trade Associations, which were intended to be instruments of colonial control but often became champions of Chinese commercial rights, improved business conditions, and investment in infrastructure, especially transport. ${ }^{32}$ The Japanese also improved the quality of human resources, not only through health policies and formal education but also through opportunities for on the job training. For while higher white collar occupations were monopolized by Japanese, behind them stood many Chinese who carried their technical and organizational experience through to the post-war years.

The American Hegemony: The Strong Phase, 1949 to the early 1960s

During the first decade after the establishment of the ROC on Taiwan, the United States played a central role in determining both the external framework and the internal policy direction of the economy. Indeed, in this decade, it is little exaggeration to say that the colonial phase of Taiwan's development continued under a new hegemon with a new agenda. The colonial behaviour was less obvious than in Japan under occupation during 1945-51, but it was powerful and omnipresent nevertheless. $^{33}$

The American framework can be discussed in terms of regional and international, political and institutional dimensions. At the international/ institutional level, the Americans established a system that set as longterm goals mechanisms for free trade, balance of payments liberalization and free capital flows. This agenda was steadily implemented throughout the 1950s and 1960s, and only went into reverse in the 1970s when the gold-dollar standard collapsed, and in the 1980s when the United States reverted to non-tariff protectionism to defend industries weakened by the world competition it had itself successfully engendered.

The regional/political framework for Taiwan was determined by American policies relating mainly to China and Japan. After 1951 these included containment of the PRC and strengthening, both economically and militarily, Japan and later South Korea. For South-East Asia the agenda was to open these economies to trade and direct investment, a huge opportunity for Japan, which was taken. Taiwan had an important place in this scenario and construction for defence and the achievement of economic stabilization therefore became urgent tasks.

32. An important example of this process can be seen in the history of the staff of the Taiwan Electric Company, Lin Bing-huo, Taiwan Denryoku Kabushikikaisha fazhanshi (The History of the Development of Taiwan Electric) (Taibei: Taiwan Electric, 1997).

33. For Japan see John Dower, Embracing Defeat. Japan in the Aftermath of World War II (London: Allen Lane, 1999). Also, John Dower, "Occupied Japan and the Cold War in Asia," in his Japan in War and Peace (London: Harper Collins, 1995). 
The internal dimension to these policies was a Taiwanese land reform, currency stabilization and a shift towards market institutions. The first two presented no fundamental problems to the KMT, whose administration was ready to correct the errors of the inflationary and currency debacle of 1945-48, when Taiwan had been forced to import these problems from the mainland. Market institutions and less corruption in public administration were, however, a far more complex problem embodying substantial scope for KMT/American conflict. Chen Yi, the KMT official put in charge of the Japanese surrender, had been wedded to concepts of economic planning which were almost indistinguishable from a communist transitional system. With over 70 per cent of the non-agricultural economy in the state sector after the seizure of Japanese assets, this approach was in some senses quite realizable. ${ }^{34}$ Moreover, with many mainlanders dependent on sinecures in the public sector for a livelihood and the KMT itself an economic beneficiary of major enterprises, conversion to a truly market-oriented industry and financial sector was to be a task that remains uncompleted after more than half a century.

The American influence in this period was exercised partly through institutions and partly through the role of American-educated administrators and economists. Taiwan economic policy at this time was inspired and administered by an exceptional galaxy of intellectual talent. Among the key government figures were C.K. Yen, Hsu Peh-yuan and S.C. Tsiang, and among economists contributing to policy discussion were T.C. Liu, John C.H. Fei and Mo-huan Hsing.

Key institutions in this period were often direct descendants of mainland institutions and came to include the Council for United States Aid (CUSA, 1948), the Economic Stabilization Board (ESB, 1951), later the International Council for Economic Co-operation and Development, and the Joint Commission for Rural Reconstruction (JCRR), later transformed into a de facto ministry. This was the Council for Agriculture, whose status has still not been regularized.

Given the size of the Taiwan trade deficit and of shortfalls of food and crucial commodities and raw materials, all of which had to be purchased with U.S. military or development aid, the American role in determining the shape of the trade sector and hence internal resource allocation was very great. There was little need for legalities when "consultation" in the joint bodies was all that was needed. In the short term, the ESB and the stabilization problem were paramount, but as the 1950s progressed the JCRR and the Industrial Development and Investment Center were able to adopt an increasingly development-oriented approach to aid allocation.

The JCRR was a particularly remarkable institution in terms of structure, history and achievements. It advised on and monitored the land reform and, through budgetary and technical influence, had a major 
The China Quarterly

Table 3: Indicators of Economic Growth, 1951-1959 (\% per annum)

\begin{tabular}{lc}
\hline Gross National Product & 7.9 \\
GNP per capita & 4.4 \\
Industrial production & 13.3 \\
Agricultural production & 6 \\
Exports as a \% of GNP & 9.8 rising to 11 \\
Imports as a \% of GNP & 14.4 rising to 20.1 \\
\hline Source: & \\
DGBAS, quoted in Neil H. Jacoby, U.S. Aid to Taiwan. \\
A Study of Foreign Aid, Self-Help, and Development \\
(London: Praeger, 1966), p. 86.
\end{tabular}

impact on all aspects of rural life. Leadership of the JCRR was exceptional with, on the Taiwan side, such remarkable men as Chiang Monlin and T.H. Shen ${ }^{35}$ Basic indicators of economic performance in the 1950s are shown in Table 3. Although the growth rates seem impressive, it is important to bear in mind the low starting point. According to estimates by T.H. Lee and S.C. Hsieh, per capita product in 1946-50 fell to only 42 per cent of its $1931-35$ peak. ${ }^{36}$ On this basis, pre-war peaks had probably not been reached by this time.

A key to understanding this decade is Table 4, which shows the structure of investment by type and source in the years covered by the American assistance programme. Two features stand out from this table: first that the United States accounted for 31.1 per cent of all investment in this period, and that this was mainly in agriculture and infrastructure; and secondly, that within domestic resources, the private sector contribution was only marginally larger than the public one. Indeed, in the 1950s proper the public sector would have been predominant. In terms of output of industry, the private only moved ahead of the public sector in 1958.

Thus the Taiwan economy in the 1950s must be thought of as a transforming, semi-socialist economy supported by American guidance and resources. This structure was partly a reflection of the Japanese period and its aftermath, but was also congruent with KMT philosophy which, following Sun, had always put the public sector as guardian of strategic economic activities and had some distrust of the market. ${ }^{37}$ Although American influence worked steadily in favour of the private sector and towards liberalization of domestic and foreign sectors, never-

35. Chiang had been Chancellor of Peking University and Minister for Education before the war and he led the JCRR through its most difficult times. Shen, a veteran of the National Agricultural Research Bureau in the Nanking administration, was probably the leading expert on the Chinese rural economy of his day. His writings on Chinese agricultural problems reveal a tremendous grasp of the agronomic and economic issues, but on the mainland, successful implementation of policies was never achieved. In Taiwan, he succeeded in putting his academic analyses and practical experience into effect.

36. Quoted in Ching-yuan Lin, Industrialization in Taiwan, 1946-72 (London: Praeger, 1973), p. 23

37. See remarks in Chien-kuo Pang, The State and Economic Transformation. The Taiwan Case (New York: Garland, 1992), ch. 2. 
Table 4: The role of Aid and Domestic Capital, 1951-1963

\begin{tabular}{lccc}
\hline Type & $\begin{array}{c}\text { Net domestic } \\
\text { investment (shares by } \\
\text { sector) }\end{array}$ & $\begin{array}{c}\text { U.S. capital assistance } \\
\text { (shares by sector) }\end{array}$ & $\begin{array}{c}\text { U.S. as a \% of total } \\
\text { in each sector }\end{array}$ \\
\hline Infrastructure & 18.5 & 44 & 74 \\
Agriculture & 12.6 & 23.8 & 58.7 \\
Industry & 46.8 & 19.4 & 12.9 \\
Human resources & 22.1 & 12.8 & 18 \\
Total public & 48 & 80.1 & - \\
Total private & 52 & 19.9 & - \\
Total & $\mathbf{1 0 0}$ & $\mathbf{1 0 0}$ & $\mathbf{3 1 . 1}$ \\
\hline
\end{tabular}

Source: 
theless by the end of the 1950s what was effectively an import substitution strategy was in considerable difficulty with the trade deficit large and growing. The performance of cotton yarn and cloth, shoes, bicycles and tyres, simple electrical and other light industry products, all potential export industries for a labour abundant economy, was weak.

Taiwan's role in Asia during this period was limited. The loss of markets first in Japan and then in mainland China was highly disruptive and led to a re-orientation of trade in which the overall share of exports to and imports from Asia dropped from 83 and 68 per cent in 1950 to 66 and 50 per cent respectively in 1960. In terms of capital flows, there were some overseas Chinese inflows and some Japanese interest, but these were on a very small scale. It was against this difficult economic background, and further threatening development in the Taiwan Straits in 1958 that a series of institutional reforms began. These included unification of the exchange rate and measures to encourage home and foreign investment, many of which foreshadowed the 19-Point Programme and were to be embodied in the Statute of Encouragement for Investment (1960), both of which had the benefit of American input. This programme was later elaborated with strong export incentives of various kinds, including the establishment of Export Processing Zones. ${ }^{38}$

\section{The American Hegemony, the Weakening Phase, 1960s to 1988}

During this period, while direct American involvement in the economy weakened markedly, the wider implications of the American-inspired world and Asian post-war systems remained with profound implications for Taiwan's economic opportunities. The year 1988 may be regarded as a terminal point since in July of that year the PRC enacted its Regulations for the Encouragement of Investment by Taiwanese Compatriots (tongbao). From this point onwards, the China factor begins to disturb the hegemonic calm of the earlier years.

Development in this phase is summarized in Table 5. In this period, there was overall high growth, a sub-period of super growth (1965-78) and an exceptional expansion of the external orientation of the economy.

Table 5: Indicators of Economic Growth, 1961-1988 (\% per annum)

\begin{tabular}{ll}
\hline Gross Domestic Product & 9.73 \\
GDP per capita & 7.58 \\
Gross Fixed Capital Formation & 11.8 \\
Trade as \% of GNP & 27.45 (1960) rising to 95.6 (1988) \\
\hline Source: & \\
Ministry of Economic Affairs, Department of Statistics, Jingji tongji nianbao \\
(Economic Statistics Annual), various years.
\end{tabular}

38. Robert Wade, Governing the Market (Princeton: Princeton University Press, 1990), is the finest general introduction to the analysis of the issues. 
How was this phase - surely the core of the concept of the Taiwan "model" - achieved? Clearly Taiwan was benefiting externally from the best of all worlds: now effectively independent of the Americans in economic management while still securing word-wide market access under the post-war international system.

The domestic foundations of success, however, were more complex. Relatively well known is the role of government, which not only continued with liberalization and policies more friendly to the private sector, but also played an active role in technology transfer and enhancement of export capabilities in the electrical and electronic industries. ${ }^{39}$ These efforts included intensified efforts to obtain learning and market access benefits through foreign investment as well as the development of "intermediary" technology institutions and establishment of the Hsinchu Science Based Industrial Park - a form of high technology export zone.

But even more important, especially in the 1960s and 1970s, was the dynamism of entrepreneurs in the small and medium-scale sector. This, as argued earlier, was partly a reflection of business development in the Japanese period, but it was also given a huge push by the arrival of the KMT and its political repression of Taiwanese culminating in the 28 February repression. During the 1950s the mainlanders monopolized the state-owned, heavy industry and bureaucratic sectors and, for most, their outlook was a short-term one, based on belief in a rapid return to the mainland. ${ }^{40}$ For the home population, basically excluded from careers in the large-scale sector of the economy and public administration, smallscale business and external markets represented the only way to wealth and status. These businesses typically used family and overseas networks not only to raise capital but also to improve technology transfer and market access. The reforms of the late 1950s and 1960s and the arrival of foreign investment provided the catalysts and facilitators for economic expansion based on these social and political foundations. ${ }^{41}$

This highly successful phase came to an end in the late 1980s for three reasons. One was the opening of China, which created opportunities and

39. An analysis of one dimension of this is John A. Mathews, High Technology Industrialisation in East Asia, The Case of the Semiconductor Industry in Taiwan and Korea (Taipei: Chung-Hua Institution for Economic Research, 1995).

40. This attitude was documented in the joint ROC-U.S. sponsored Urban and Industrial Survey of Taiwan (1953-1954). Reprinted in Annie H. Chou, Documentary Collection on U.S. Aid to ROC, 1948-1965, Vol. III, Technical Assistance (Taibei: Academic Historica, 1998), esp. pp. 108-133. This remarkable report not only describes the current situation but also deals exhaustively with the problems of converting an overstaffed, state-dominated industrial sector into a vibrant, export-oriented private economy.

41. The typology and origins of the Taiwanese industrial structure are extensively discussed by contributors to Ku P'u-hsiung (ed.), Taiwan de gongyehua: guoji jiagong jiqi de xingcheng (Taiwan's Industrialisation. The Formation of an International Processing Base (Taipei: Jenchien Publishing), esp. ch. 1. The economic significance of the February 28th incident is analysed in, Weng Jia-xi, Economic Policy and Transformation Model in the Early Period of Taiwan's Recovery. The flexibility and activism of the small sector remains important in the technically upgraded economy of the 1990s; see Chi Schive, "How did small and medium enterprises in Taiwan survive the crisis?" mimeo conference paper, Taibei, 1999. Politically or religiously excluded minorities have often used the economy as a means of escape, but rarely is such a group a majority in its own territory. 
dilemmas of a new kind for Taiwanese industrialists. Secondly, this opening coincided with a new trend towards regionalized production networks - networks substantially driven by demand in markets in Europe, the United States and Japan. Uncertainty and relocation engendered by these developments contributed to a severe macroeconomic problem in Taiwan in 1986-88, in which domestic savings began to far exceed investment. Thus Taiwan in the 1990s faced a rapidly changing and problematic environment.

\section{Changing Hegemonies and the China Factor, the 1990s}

A summary of Taiwan's performance since 1992 is provided in Table 6. These data show a steady economic performance extending right through the Asian crisis. Compared to the late 1980s, the macroeconomic balance is much healthier, and although unemployment has risen, the impact of the crisis has been much smaller than, for example, that in Hong Kong.

The Asian context of Taiwan's development changed significantly during the 1990s. One reason for this was that the role of FDI became much more extensive and complex in operation and effect. FDI has been a factor in Asia since the 1960s, but mainly for simple transference of labour intensive operations and the establishment of greater raw material security. In the 1990s, however, FDI transformed the ASEAN group through export-oriented primary industrialization, while the second-tier industrializers including Taiwan became investors themselves. Overall the division of labour within Asia became much more complex, interdependent and irreversible.

The opening of China made a large contribution to this process. In addition to the attractions of a low-wage manufacturing base it dangled before investors promise of eventual entry into a huge domestic market. Hong Kong role's role was very important here. By now a high-cost location for production, the territory had developed over 150 years a huge array of entrepôt and service skills that enabled Hong Kong industrialists and others using Hong Kong as a regional base to tap into Chinese possibilities. Finally, the ending of the Cold War and Chinese economic decentralization opened the borders of almost the whole perimeter of China to resource flows and trade. This created the possibility of crossborder nodes of interaction, specialization and hence regional trade competitiveness. ${ }^{42}$

With the encouragement of facilitating legislation and active encouragement of all kinds from the PRC, Taiwanese firms responded strongly to the new opportunities. Chin Chung has identified three major categories of Taiwanese FDI in China: small-scale firms that relocate labour-intensive production; larger-scale, domestic-oriented firms that

42. For a valuable overview of these processes in Asia generally during the 1990s, work by Francois Gipouloux is very helpful, for example, "L'Asie orientale: un nouvel atelier nippon?"' in Claude Auroi, L'integration regionale dans le monde, innovations et ruptures (Paris: Karthala, 1994). 
Table 6: Taiwan's Macro-economic Performance, 1992-1998

\begin{tabular}{lrrrrrrr}
\hline & 1992 & 1993 & 1994 & 1995 & 1996 & 1997 & 1998 \\
\hline Real GDP growth (\% per annum) & 6.8 & 6.3 & 6.5 & 6 & 5.7 & 6.8 & 4.8 \\
Capital formation as \% of GNP & 24.4 & 24.8 & 23.6 & 23.4 & 21.1 & 21.9 & 22.3 \\
Gross savings as \% of GNP & 28.3 & 27.8 & 26.1 & 25.3 & 24.9 & 24.6 & 24.2 \\
Unemployment (\%) & 1.5 & 1.5 & 1.6 & 1.8 & 2.6 & 2.7 & 2.7 \\
Price change (GDP deflator, \% per annum) & 3.9 & 3.5 & 1.8 & 1.9 & 2.7 & 1.8 & 2.6 \\
\hline
\end{tabular}

Price change (GDP deflator, \% per annum)

Source:

Council for Economic Planning and Development, Taiwan Statistical Data Book, 1999. 
invest seeking market expansion in China; and firms with MNC characteristics that seek to relocate the lower end of their product range in China, while maintaining service functions, $\mathrm{R} \& \mathrm{D}$ and market presence at home. ${ }^{43}$ The scale of these investment flows is debated, but according to Chung Hua Institute estimates, in 10 out of 15 product categories China now accounts for more than half of all foreign investment. ${ }^{44}$ Trade flows and structures reflect investment activity. By 1998 aggregate trade dependence had risen above 10 per cent but with trade heavily in favour of Taiwan. Whereas the mainland share of Taiwan's exports was 17.9 per cent in 1998, import dependence was only 3.9 per cent. For China the figures were 2.34 per cent for exports and 14.16 per cent for imports. ${ }^{45}$ The trends in exports, FDI and communications are shown in Table 7.

Taiwan's role in Asia during the 1990s has followed regional trends and become more integrated and more varied. Not only have Taiwanese trade and FDI activities risen within Asia, but Taiwan has taken on significant activities in aid, notably in Vietnam. Also, during the Asian financial crisis, Taiwan supplied financial emergency support within the region. The question for the future is whether these processes of integration and growth in Asia, and especially integration with the China mainland, are sustainable.

\section{China and Regional Integration}

With trade, investment and some technology transfer activities growing rapidly between Taiwan and the mainland, an optimistic scenario would project these trends into the future, with appropriate restructuring and internal development occurring in Taiwan. There are, however, serious obstacles to this. First, as Chin Chung has pointed out, much investment has been by small firms whose intangible assets are very restricted, often limited to the skills embodied in the boss or a small group of people, and whose competitiveness depends on tight but flexible horizontal networking. Such firms will need either to migrate with their networks, or to develop new local networks in their overseas location. In either case, the hollowing out effects in Taiwan might be serious. Secondly, there are the major and seemingly growing political risks incurred on the mainland. In time of crisis, Taiwan businessmen can be arrested and business relations subject to arbitrary disruption by central or local authorities. Further, as Japanese analysts have pointed out, the role of Hong Kong as a large-scale intermediary of Taiwan-mainland linkages is now also an additional hostage to fortune. ${ }^{46}$

43. "Industry characteristics and FDI strategy: a three way typology of Taiwanese investment in Mainland China," in Joseph S. Lee, The Emergence of the South China Growth Triangle (Chung-Hua Institution for Economic Research, 1996).

44. Quoted in Nichū keizai kyōkai journal (Journal of the Japan-China Economic Co-operation Council), No. 64 (March 1999).

45. Mainland Affairs Council, Cross Strait Economic Statistics Monthly, December 1999. These data are MAC estimates.

46. For a list of the issues see "From the perspective of Taiwan see the significance and influence of the reversion of Hong Kong to China," Nichū keizai kyōkai, No. 34 (July 1996). 
Table 7: Indicators of Taiwan-Mainland Linkages, 1992-1998

\begin{tabular}{|c|c|c|c|c|c|c|c|}
\hline & 1992 & 1993 & 1994 & 1995 & 1996 & 1997 & 1998 \\
\hline Rate of growth of exports Taiwan to mainland (valued in US dollars) & 40.8 & 32.7 & 14.5 & 19.8 & 6.7 & 8.3 & -11.7 \\
\hline Contracted Taiwan investment (billions US dollars) & 5.543 & 9.965 & 5.395 & 5.777 & 5.141 & 2.84 & 2.982 \\
\hline
\end{tabular}

Indirect telephone calls Taiwan to mainland (millions)

Note:

Trade data are MAC estimates and investment data are mainland official statistics.

Source:

Mainland Affairs Council, Cross Strait Economic Statistics Monthly, December 1999 
Real as both these risks are, there is a more fundamental problem. It was argued above that the economic integration of Taiwan and the mainland has been part of a wider process taking place around the China periphery. This integration has been based on gains that occur in localities where mutual benefits from localized direct trade are immediate, and where the end result of integration through FDI and other flows is the creation of nodes of competitiveness for the region as a whole, vis-à-vis other regions or countries. This competitiveness occurs because resources and capabilities match to create strong externalities for the firm. Further, in the high technology sector, not only are there gains where firm capabilities are complementary, but partners at approximately similar levels of technological capability can also share costs and reduce both market and technological uncertainties by devising close inter-firm arrangements of many kinds. However, these gains are only available where business systems in a broad sense are compatible, where firms and other agencies can work together under conditions of mutual confidence and transparency, and where respect for intellectual property rights is strong. ${ }^{47}$ Where these conditions apply, this not only enables existing potentialities to be taken advantage of but, much more important in the long term, the partners can engage on a powerful mutual learning process. Such a process is intrinsically difficult to manage because it cannot be reduced to predictable outcomes and planned, measurable gains for both parties. ${ }^{48}$ It might be argued that the growth of cross-Straits relations demonstrates that these conditions already apply. How, otherwise, would the Taiwan-Xiamen-Fujian linkage have grown so rapidly? Unfortunately this early development does not dispose of the problem. There is no doubt that language, kinship and other ties have played a role in facilitating Taiwan FDI on the mainland. However, the mainland partners in this have often been cadres, whose function is to give permissions, mediate with local economic actors and capture what gains they can. This is sufficient at an early stage of development when the main objective of FDI is to combine cheap labour and land resources with Taiwanese inputs and management, and get the benefits of "jobbing" OEM production. However, what is called for now in terms of the stage of development of each economy, and of recent PRC regulations and policies for FDI, is a much more profound relationship in which company-to-company technology and knowledge transfers will take place. Given the profound shortcomings of the Chinese corporate system and the weaknesses of the investment environment generally, this will be difficult for any investor. But it is obviously particularly difficult for Taiwan-based investors, given

47. For the regional dimension of this argument see Clive Lawson, "Towards a competence theory of the region," Cambridge Journal of Economics, Vol. 23, No. 2 (March 1999), and the important new study by Frans Boekema et al. (eds). Knowledge, Innovation and Economic Growth. The Theory and Practice of Learning Regions (Cheltenham: Edward Elgar, 2000). The latter is primarily a European study but its analysis has much wider applicability.

48. Charles F. Sabel, "Learning by monitoring. The institutions of economic development," in Lloyd Rodwin and Donald A. Schon, Rethinking the Development Experience. Essays provoked by the Work of Albert O. Hirschman (New York: Brookings Institution, 1994). 
the conflictual nature of the cross-Straits political relationship. The costs and absolute barriers to surmounting this problem will make other locations in Asia increasingly more attractive to Taiwanese investors than mainland China. The flattening of the trade and FDI curves both for Taiwan and indeed the general decline of interest in FDI in China both suggest that this is already happening.

Since 1995, much emphasis has been placed on the role of the APROC scheme as a means of improving Taiwan's position as an East Asian hub, somewhat along the lines sketched by Takahashi over 60 years ago. This scheme was developed with sharp appreciation of the regional and global trends in trade, production and financial systems. Through a long-term plan for transportation, communications, financial, bureaucratic and legal reforms, the scheme aims to make Taiwan a competitor to Hong Kong, Shanghai and other regional service and high technology hubs. Progress has been made, although there are some arguments, notably with the Europeans, who do not agree with the Taiwan authorities about where the clock has got to. ${ }^{49}$ There is clearly potential in APROC and it represents a serious effort to push Taiwan's place in Asia into its logical position, but it does not enable the economy to overcome fundamental cross-Straits difficulties such as those outlined above.

\section{Conclusion}

Taiwan has been one of the most remarkable economic performers of the 20th century. Seen over the long term, this small island economy has for most of its history been subject to external political control, whether by the mainland as part of a unified Chinese polity or, in very different modes, by Japan and the United States. These pressures have arisen in considerable part from Taiwan's physical location, so close to China that although not a part of the pre-Qing imperial system, trade, migration and political claims arose in a naturally predictable sequence. The small size of Taiwan made external pressures hard to resist and hence the island has found itself unavoidably implicated in the rise and fall of great powers in Asia. Taiwan has both benefited and suffered from these experiences as each hegemon has sought to impose its own agenda on the island. It benefited in the sense that each was a source of technical and institutional learning, but lost in that each also had agenda items that were not in Taiwanese interests.

At certain times, as hegemons have weakened or been challenged, the island has enjoyed substantial periods of de facto independence. These include the early 17 th century, the latter part of the 19th and a period which could be dated from somewhere in the 1960s to the present day. It is clearly now in a phase of transition, which may be short but could last a long time. 
As compared to earlier windows of independence, however, the revolutions in technology and economic institutions that began in the late 20th century present new issues and offer elements of a different kind of framework for Taiwan's future. The revolutions make possible new kinds of regional and world integration and economies that do not participate will not be able to compete. In these scenarios, the future of the national economy as a manageable, independent unit is being called into question. This has disadvantages, but for Taiwan there is the important advantage that simple military domination is no longer possible without the dominator paying an insupportable price in terms of its own economic welfare and security. Bellicose nations will simply be excluded from the inner circle of the economically and technically advanced. How Taiwan will manage a future with these elements remains unclear. But the new scenario suggests that in the long run the quality of resources and a capacity for mutually beneficial relationships are what will count, and that the strengths of a society will continue to depend more upon the software of skills and good conduct than on the hardware of physical power. 